\title{
PERFORMANCE OF BALI BULL IN GREENLOT FATTENING BY FARMERS WHEN RAINY SEASON IN TIMOR ISLAND
}

\author{
P. K. Tahuk and A.A. Dethan \\ The Agriculture Faculty of Timor University-East Nusa Tenggara. \\ Jl . Mayjend El Tari, Kefamenanu, Center of North Timor Regency-85613 \\ CorrespondingE-mail: paulklau@yahoo.co.id
}

Received September 12, 2010; Accepted November 21, 2010

\begin{abstract}
The objective of this research was to determine the performance of Bali bull in rainy season under feedlotting management on farmer level in Timor Island. Twenty Bali bulls with 2.0-2.5 years old on the basis of teeth eruption were used in this study. Feed for animals was field grass, king grass and corn straw. The type, quantity and quality of feed given in accordance with the habits of farmers in the fattened cattle. Research was conducted by direct observation in farmer management during rainy season. Data measured were daily gain, feed consumption and feed conversion. The data collected was tabulated and analyzed descriptively. The result showed that the average of daily gain weight was 0.53 $\mathrm{kg} / \mathrm{head} / \mathrm{d}$, dry matter intake was $3.88 \mathrm{~kg} / \mathrm{head} / \mathrm{d}$ and feed conversion was $7.55 \mathrm{~kg}$ DM/kg daily gain. In conclusion, performance of Bali bull fattened at farmers level with forage in the rainy season could be improved.
\end{abstract}

Keywords : Bali cattle, Farmer, Performance, Feedlot, Rainy Season Timor Island

\section{INTRODUCTION}

Bali cattle is one of the leading commodities in the production of meat to meet national meat demand and as the export commodity. To ensure maximum meat production of Bali cattle, fattening is an important alternative that needs to be done. According to Dyer and O'Mary (1977) feedlot cattle was a business aiming to obtain the meat production based on increasing body weight through the provision of high quality feed and with the shortest possible time. By fattening, important measures used in assessing the productivity of cattle such as daily gain, feed conversion and efficiency, carcass and meat production and feed cost per gain can be optimized.

Fattening cattle (In Indonesian: paronisasi) for people on the Island of Timor is not new model because it has integrated with community life and it has been done from generation to generation. However, feedlot conducted by farmers on the Timor Island is not adopt the theoretical concepts relating to implementation. There has not been quality improvement efforts through the preparation of feed rations to meet the needs of livestock.

In addition to the quality of feed that has not been a concern, the availability of feed in the Timor Island is strongly influenced by climatic factors. In the rainy season, it can be provided the need of quantity and quality of livestock feed. In this season individual growth is good. Meanwhile, in the dry season feed availability becomes a serious problem that is very disturbing livestock productivity. Growth patterns of livestock in general is negative because of insufficient feed quality..

Generally, it could be depicted that feed quality factor becomes one of the main factors determining the quality of meat that has not been a concern of farmers in Bali cattle fattening on Timor Island. Feed given improvise without considering whether adequate nutrients derived cattle or not. Similarly with forage for fattening (Pasture fattening or greenlot fattening) becomes most adopted by farmers or ranchers. As a result, the livestock growth was not optimum as indicated by low weight gain and poor feed conversion.

The length of fattening period also indicated a serious problem in relation to poor quality of feed. The average length period of fattening in the farmer ranged from 12 to 24 months, a period of very slow.

If cattle are fattened at the age of 24 months 
( 2 years), then it will produce meat at age 36-48 months (3-4 years). According Ngadiono to et al. (2008), better level of feed intake in cattle will directly increase in growth, resulting in a relatively short time for to optimum growth and yield more meat due to higher slaughter weight. In addition, animal productivity could be improved by improving the feed quality (Leng, 1993), such as the provision of feed supplements. The productivity of animal in the form of body weight gain is the rest of metabolizable nutrients or energy after being utilized for their body maintenance (Purnomoadi et al., 2006).

Although fattening of livestock by farmers on the Timor Island has become a tradition inherited from ancestors, but that fattened livestock productivity is not certain because it is still limit research report related to the fattening of beef cattle. Parameters to assess the productivity of livestock in the feedlot is not certain. This makes difficulty in making policies related to increasing productivity of Bali bull that are fattened in the level of farmers.

The objectives of this research were to determine the performance of Bali Bull in rainy season under feedlotting management on farmer level in Timor Island from Average Daily Gain (ADG), feed consumption (dry matter intake/DMI) and feed conversion.

\section{MATERIALS AND METHODS}

\section{Location}

This research was conducted at Mekar Sari farmers' group, Tesa village, Laen Mane, Belu regency, East Nusa Tenggara. The number of members involved in this study was 20 people. Research was conducted for three months from January to March 2010, including preparation of data collection and data processing.

\section{Materials}

The animal used in this study were 20 Bali bull belonged of farmers with an average of was 2 to 2.5 years (estimated based on teeth eruption and replacement of incisors), with initial weight ranged from $135.1 \mathrm{~kg}$ to $178.4 \mathrm{~kg}$ or average body weight were $156.75 \mathrm{~kg}$.

Feed used in this study was native grass, kingrass and corn straw. Feeding for cattle were not same among farmers because it depends on the availability of feed and the ability of farmers to provide them. Water were available every day. Nutrient compositions of the feedstff on the fattening process are presented in Table 1.

The tools used in this study is hanging scales PSB Super Quality brands, capacity to $25 \mathrm{~kg}$ weight was used for weighing forage. Weighing tool with precession brand M.970002 for capacity $1000 \mathrm{~kg}$ was used for weighing Bali bull's body weight. This study was an observational research. Variable measurement was conducted every two weeks during the seven time.

\section{Variable}

Variables observed in this study were: Average Daily Gain (ADG), obtained by the final weight minus initial weight divided by long study (kg / head / day). Feed Consumption (Dry Matter Intake/DMI) was calculated by multiplying the amount of feed given subtracted by residual feed intake and then was multiplied by the DM content of the feed. Feed Conversion was obtained by comparing the dry matter intake with Average Daily Gain of livestock.

\section{Data Analysis}

Data were analyzed by descriptive statistics

Table 1. Feed Nutrient Composition

\begin{tabular}{lccc}
\hline \multicolumn{1}{c}{ Nutrient } & Natural Grass & Kingrass & Corn Straw \\
\hline Dry Matter Total (\%) & 21.70 & 15.12 & 23.90 \\
Organic Matter (\% DM) & 87.45 & 90.15 & 88.92 \\
Crude Protein (\% DM) & 5.15 & 10.38 & 4.58 \\
Crude Fat (\% DM) & 2.15 & 4.72 & 1.79 \\
Crube Fiber (\% DM) & 31.88 & 28.04 & 34.88 \\
Nitrogen Free Ekstrak (NFE,\% DM) & 48.28 & 47.01 & 47.67 \\
Gross Energy (Kcal/kg) & 3773 & 4073 & 3810 \\
\hline
\end{tabular}


according to Nasir (2003) by using Statistical Product and Service Solution (SPSS) Version 15 in accordance with directions Santoso (2006).

\section{RESULTS AND DISCUSSION}

\section{Average Daily Gain (ADG)}

Average daily gain (ADG) of cattle fattened at Mekar Sari Farmers Group is presented Table 2. It can be seen in Table 2 that the weight daily gain Bali Cattle during the study ranged from $0.35 \mathrm{~kg} /$ head/day to $0.73 \mathrm{~kg} / \mathrm{head} /$ day with an average of $0.53 \mathrm{~kg} / \mathrm{head} /$ day. This daily gain elated to the rainy season which take advantage of the availability of feed in quantity and quality when compared with quality in the dry season.

The ADG in this study was not maximum because fattening with forage (Greenlot Fattening) must be supported by higher quality of forage, especially legume. In this research, forage given is non legume, mainly dominated by field grass, while kinggrass only in small quantities (Table 2). If the quality of feed was poor then the growth of livestock will also be not maximum.

According to Jelantik (2001), forage quality in the East Nusa Tenggara Province was various. and highly influenced by seasonal factors. The peak content of nitrogen $(\mathrm{N})$ of the highest field grasses that growth in natural grasslands of NTT in the rainy season is in December, January and February to March months. The peak decrease of $\mathrm{N}$ on field grasses in August, September, October and November, which is the dry season.

Daily weight gain of Bali bull in the feedlot with forage in the rainy season in this study is quite high. This is an indicator of nutrient adequacy to meet the requirement of body maintain and production, especially increasing body weight as stated by Purbowati et.al (2008).

Paat and Salam research report (1991) showed that the growth curve of Bali heifers was linear in the rainy season. Daily weight gain was about $413.0 \mathrm{~g} / \mathrm{h}$ ead/day without the supplement. This condition showed an indication on good growth of cattle in natural pastures during rainy season.

The results of study was higher than reported by Wirdahayati and Bamualim (1990) that daily gain of Bali heifers in extensive conditions on natural pastures in East Nusa Tenggara was about
$490 \mathrm{~g} / \mathrm{head} / \mathrm{d}$ during the rainy season. Meanwhile, deceasing of body weight in dry season was about $350 \mathrm{~g} / \mathrm{head} / \mathrm{d}$ or an average of $140 \mathrm{~g} / \mathrm{head} / \mathrm{d}$ throughout the year. This is caused by the different of raising patterns. Mullik et al. (2009) reported that growth rate of Bali heifers grazing native pasture during wet season in Timor was low $(35 \mathrm{~g} / \mathrm{d})$.

ADG was the parameter used to measure the growth of cattle when feed consumption has exceeded the needs for maintenance (Tillman et al, 1998). According to Dyer and O'Mary (1977) to achieve maximum growth in fattening cattle, the feed must be in good quality. The quality of feed for fattening is usually based on the level of protein, that was $12-15 \%$ and energy (TDN) of $70 \%$. It was clear that growth rate of cattle is affected by many factors, such as quality of feed, sex, hormonal state and environmental condition (Tahuk et al., 2008).

\section{Feed Consumption (DM)}

Consumption of dry matter (Dry Matter Intake/DMI) was indicator to assess the productivity of livestock. Average dry matter intake during the study is presented in Figura 1 and Table 2.

The results of this study indicated that total consumption of dry matter of Bali bull fattened ranged from $3.46 \mathrm{~kg} / \mathrm{head} / \mathrm{d}$ to $4.39 \mathrm{~kg} / \mathrm{head} / \mathrm{d}$ with an average was $3.88 \mathrm{~kg} / \mathrm{head} / \mathrm{d}$. This DMI when calculated from body weight was $2.26 \%$ of BW.

The results of study was also still in accordance with the opinion of Kearl (1982) who recommends that bull at $150 \mathrm{~kg}$ weight of maintaining BW requires DMI of $3.0 \mathrm{~kg}$ or $2.0 \%$ of body weight. Meanwhile, if the expected ADG was $0.25,0.50$, and $0.75 \mathrm{~kg} / \mathrm{d}$, the consumption of DM was $3.8,4.2$, and $4.4 \mathrm{~kg} / \mathrm{d}$ or $2.5,2.8$ and 2 . $9 \%$ of the body weight. Dry matter intake in this study was enough to increase daily gain of fattening cattle in the rainy season at the farmers level. This condition is caused by better quality of field grass in the rainy season, thus increasing the palatability of feed.

Nutrient content of feed has a significant effect on the growth of livestock when the quality and quantity is provided sufficiently. Feed intake in cattle was varied depending on body size, age and condition of livestock, feed palatability and kind of feed, nutrient content and the environment (Ensminger, 1987; Tillman et al., 1998). 
Table 2. Average Daily Gain (ADG), Dry Matter Intake (DMI) and Feed conversion of Bali Bull On Greenlot Fattening By farmers When Rainy Season In Timor Island

\begin{tabular}{lc}
\hline \multicolumn{1}{c}{ Variable } & Result of Observation \\
\hline Initial Body Weight $(\mathrm{kg})$ & 135.10 \\
Final Body Weight $(\mathrm{kg})$ & 178.40 \\
Body Weight Gain $(\mathrm{kg})$ & 43.30 \\
Average Daily Gain $(\mathrm{kg})$ & 0.53 \\
Total Dry Matter Intake $(\mathrm{kg})$ : & 3.88 \\
Dry Matter Intake of field grass & 3.30 \\
Dry Matter Intake of Kinggrass & 0.36 \\
Dry Matter Intake of corn straw & 0.22 \\
Feed Conversion (kg DM/kg ADG) & 7.55 \\
\hline
\end{tabular}

\section{Feed Conversion}

Average feed conversion of animal in this research is presented in Table 2. In Table 2, the average feed conversion was $7.75 \mathrm{~kg} / \mathrm{kg}$ gain, ranged 7.07 to $10.95 \mathrm{~kg} / \mathrm{kg}$ gain. Feed conversion value of 7.75 indicated that to produce one kilogram of body weight requires $7.75 \mathrm{~kg}$ DMI of feed. Feed conversion ratio obtained in this study was relatively high. Feed conversion was influenced by the quality of ruminant (including the adaptability of the feed given), the quality of the feed ingredients and feeding method used (Tahuk et al., 2008). According to Martawidjaja et al. (1999), feed conversion in ruminants is influenced by the quality of feed, the body weight gain and digestibility values. In a high quality of feed, livestock will grow more quickly (Kuswandi et al., 1992).

In this study, feed composition was dominated by field grass containing $5.15 \%$ crude protein and high crude fiber (31.88\%). The high crude fiber causes the microorganism activity of in the digestion of feed in the rumen is not optimum and give a poor feed conversion.

\section{CONCLUSION}

The use of field grass in Bali bull fattened by farmers in the rainy season could increase body weight gain, consumption and feed conversion. Average Daily Gain was $0.53 \mathrm{~kg} / \mathrm{head} / \mathrm{d}$, Dry Matter Intake was $3.88 \mathrm{~kg} / \mathrm{head} / \mathrm{d}$ and feed conversion was $7.55 \mathrm{~kg} / \mathrm{kg}$. dailiy gain.

\section{REFERENCES}

Dyer, I.A and C.C O'Mary. 1977. The Feedlot. Second Ed. Lea and Febiger, Philadelphia.

Ensminger, M.E. 1987. Beef Cattle Science. Animal Agriculture Series. $3^{\text {rd }}$ Ed. Interstate Printers \& Publisher. Inc. Danville, Illinois.

Jelantik, I.G.N. 2001. Improving Bali Cattle (Bibos Banten Wagner) Production Trough Protein Supplementation .Ph.D Thesis. Departement of Animal Science and Animal Health, The Royal Veterinary and Agricultural University, Copenhagen, Denmark.

Kuswandi., M. Martawidjaja., Z. Muhammad., B. Setiadi dan B.D. Wiyono. 1992. Penggunaan $\mathrm{N}$ mudah tersedia pada pakan basal rumput lapangan pada kambing lepas sapih. JITV. 5(4) :21 - 223 .

Leng, R.A. 1993. Quantitative ruminant nutrition Agreen science. Austr. J. Agric. Res. 44: 363380 .

Martawidjaja, M., B. Setiadi; dan S.S. Sitorus. 1999. Pengaruh tingkat protein-energi pakan terhadap kinerja produksi kambing kacang muda. JITV. 4(3):167-172.

Mullik, M.L. and B. Permana. 2009. Improving growth rate of Bali cattle grazing native pasture in wet season by supplementing high quality forages. JITV. 14(3):192-199.

Nasir, M., 2003. Metode Penelitian. Ghalia Indonesia, Jakarta.

Ngadiyono, N., G. Murdjito., A. Agus dan U. Supriyana. 2008. Kinerja produksi sapi 
Peranakan Ongole jantan dengan pemberian dua jenis konsentrat yang berbeda. J. Indonesian Trop. Anim. Agric. 33(4):282289.

Paat, C. P. dan R.Salam. 1991. Pertumbuhan sapi Bali dara pada pastura alam dengan dan tanpa penambahan pakan penguat. Sub Balai Penelitian Ternak Gowa, Ujung Pandang. Jurnal Ilmiah Penelitian Ternak Grati. 2(1): 37 - 40. ISSN 0853-1285.

Parakkasi, A. 1999. Ilmu Nutrisi dan Makanan Ternak Ruminan. Cetakan Pertama. Penerbit UIP, Jakarta.

Purbowati, E., C.I. Sutrisno, E. Baliarti, S.P.S. Budhi dan W. Lestariana. 2008. Pemanfaatan energi pakan komplit berkadar protein-energi berbeda pada domba lokal jantan yang digemukkan secara feedlot. J. Indonesian Trop. Anim. Agric. 33(1):59-65

Purnomoadi, A., B.C. Edy, R. Adiwinarti, and E. Rianto. 2007. The performance and energy utilization in Ongole crossbred cattle raised under two level supplementations of concentrate to the rice straw. J. Indonesian Trop. Anim. Agric. 32(1) :1-4.

Santoso, S. 2006. Menguasai Statistik di Era
Reformasi dengan SPSS 15. Penerbit PT. Ex Media Komputindo Kelompok Gramedia, Jakarta.

Sumadi and Soeparno. 1991. Produksi karkas, faktor yield grade dan kualitas daging dari tiga bangsa sapi yang dipelihara secara feedlot. Dalam: Seminar Nasional HasilHasil Penelitian Perguruan Tinggi. Tanggal 21-24 Januari 1991. Pusdiklat Depdikbud Sawangan, Bogor.

Tahuk, P. K., E. Baliarti and H. Hartadi. 2008. Kinerja kambing Bligon jantan pada penggemukan dengan level protein pakan berbeda. Buletin Peternakan, Universitas Gadjah Mada. 32(2): 121-135.

Tillman, A.D., H. Hartadi, S. Reksohadiprodjo, S.Prawirakusomo and S. Lebdosoekojo. 1998. Ilmu Makanan Dasar. Gadjah Mada University Press, Yogyakarta.

Wirdhayati, R.B. dan A. Bamualim. 1990. Penampilan produksi dan struktur populasi temak sapi bali di pulau Timor NTT. Prosiding Seminar Nasional Sapi Bali. Universitas Udayana, Denpasar, Bali, September 20-22, 1990. 